\title{
Reviewing the Effects of Leader-Member Exchange on Job Crafting via Moderated- Mediation Analysis: A Study on Teachers
}

\author{
Mustafa BABADAĞ \\ a Muğla Sitkı Koçman University, Muğla, Turkey. mustafababadag@mu.edu.tr
}

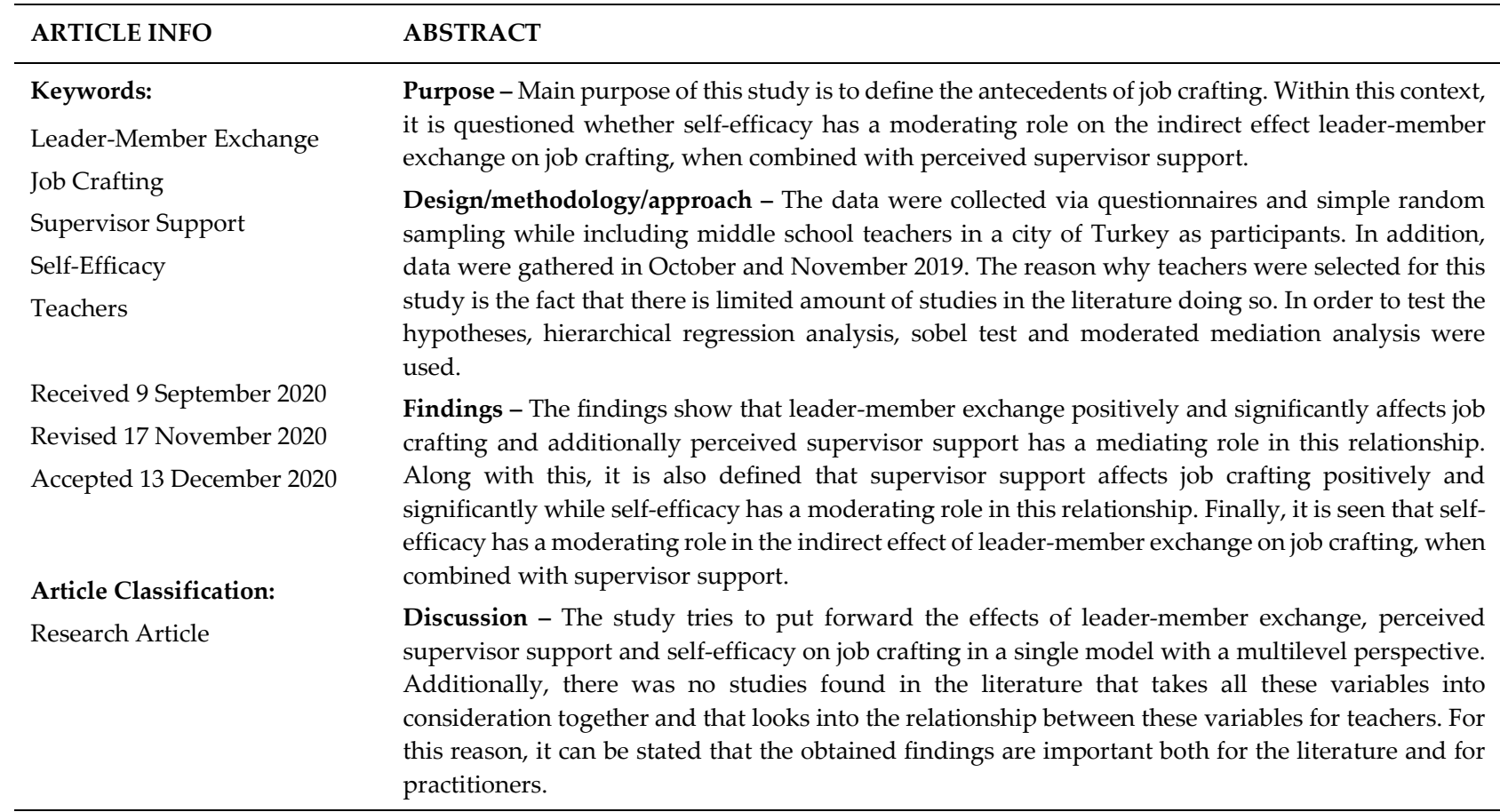

\section{INTRODUCTION}

From past to present, employees have been seen as one of the important factors for organizations. The reason for this is the fact that the behaviours, attitudes, and performance of the employees is what makes the organization reach its goals. Correspondingly, the behaviours of the teachers can be evaluated as even more important for the organizations they work for. Because in most of the organizations except for schools, the behaviours and attitudes of the employees only concern the organization's future, teachers' behaviours and attitudes affect both the success and future of the organization as well as the students. For this reason, it is seen as important to look into the behaviours and attitudes of teachers for the future of organizations, students, and societies. Additionally, when the literature is reviewed, it is seen that positive behaviours and attitudes of the employees bring along important outcomes such as increasing their performances (Mallick et al., 2014) and their work engagement (Garg et al., 2018). Thus it is needed to uncover and increase the positive behaviours and attitudes of teachers as well.

Job crafting, which is evaluated as a proactive behaviour type and which refers to changes made in the taskrelated, relational, cognitive scope of work (Wrzesniewski and Dutton, 2001), is believed to be a factor revealing the positive behaviours of the employees (Ingusci et al., 2016). Correspondingly, studies show that job crafting increases the performance, health, and job satisfaction of the employees (Alonso et al., 2019; Leana et al., 2009; Zito et al., 2019). On the other hand, scientific developments, advancements in information and communication technologies, and political transformations made it essential to have individuals who are able to make critical judgements, who are ready to communicate to solve problems and cooperate, who are willing 
to search for alternatives to form a better society, who are autonomous (Alonso et al., 2019) and who are able to make changes in the scale of their work. However, when compared to other occupations, it is reckoned that teachers have limited power and authority in making important decisions related to their work. This limited authority manifests itself more clearly in the Turkish education system. The reason for this is the centralistic structure of the Turkish education system, which means curriculums, textbooks, lessons, and in-service training are defined by the central authority, out of the teachers' control (Colak et al., 2017). For this reason, it seems difficult for teachers to display job crafting behaviour in the context of Turkey. Nonetheless, it is presumed that with their self-confidence and with supervisor support, teachers can overcome this and display job crafting behaviour. In this context, this study focuses on the effect of high-quality leader-member exchange, perceived supervisor support and self-efficacy on job crafting.

The contributions of this study to the literature from three aspects. To begin with, it has been seen that there are indeed studies that relate the variables of leader-member exchange, job crafting, supervisor support and self-efficacy with each other. But these studies are very few. Additionally, in the literature, it is seen that no studies are taking these variables altogether as a subject and also defining the mediating role of supervisor support within the relation between leader-member exchange and job crafting and the moderating role of selfefficacy within the relationship between supervisor support and job crafting. In addition to all these, no studies found investigating the moderating role of self-efficacy within the indirect effect of leader-member exchange with perceived supervisor support on job crafting. For this reason, the study evaluates whether these factors have any effect on job crafting with a moderated mediation model and with a multi-level perspective. The study aims to contribute to the literature significantly with its findings. Secondly, it has been found that there is a limited number of studies determining the job crafting behaviours of teachers and no studies are looking into the effect of high-quality leader-member exchange on job crafting behaviour of teachers. On top of this, this study does not only focus on the effect of high-quality leader-member exchange on job crafting behaviour of teachers, but it also tries to define the effects of perceived supervisor support and self-efficacy in this relationship. Finally, the study will contribute to the literature in a cultural context as well. Because Turkey is a country that has a high power distance (Hofstede, 1983). And in a society with high power distance, individuals are expected to show low job crafting behaviours (Wang et al., 2016). In a society with high power distance, is the job crafting behaviour indeed at a low level? This study seeks answers to this question and tries to significantly contribute to the literature.

\section{CONCEPTUAL FRAMEWORK AND HYPOTHESES}

\subsection{Leader-Member Exchange}

To begin with, Leader-Member Exchange Model (Graen and Uhl-Bien, 1995), which was developed based on Vertical Dyad Linkage Model, which was suggested by Dansereau et al. in 1975, proposes that leaders develop different relations with each audience (employees) (Berdicchia, 2015).

According to the theory, while the relationship between the leader and the employee can be shaped solely by the formal rules stated in the work agreement (Graen and Cashman, 1975), it could also be developed outside of these formal rules (Sparrowe and Liden, 1997). The determining factor at this point is the perception of the leader towards his/her followers. This perception leads the leaders categorizing subordinates within the organization as "high-quality $\operatorname{lm} x$ group" and "low-quality $l m x$ group" (Radstaak and Hennes, 2017). Leaders especially choose this path and bond with certain employees as time, energy and resources are limited (Alshamasi, 2012). The leader-member relationship only builds up over time as they learn more about each other (Gerstner and Day, 1997). It is reckoned that from this angle, the Leader-Member Exchange Theory can be grounded on Role Theory and Social Exchange Theory (Venkataramani et al., 2010). Because, in the LeaderMember Exchange Theory, the relationships originates between leader and followers are based on a series of role behaviours. The first step is the step of taking a role and here, the leader conveys his/her expectation out of this role and expects a response from his/her followers about this expectation (Sin et al., 2009). Additionally, the role-taking step reflects the period in which the employees have recently started the job and they do not know each other with the leader (Cekmecelioglu and Ulker, 2014). For this reason, it is thought that the relationship between the leader and the employees is shaped by whether there is any similarity in terms of demographics or personality (Bolat 2011). The second step is explained as role-playing. The role-playing stage is when the followers fulfill the role or not, which is given to them by the leader, as per the leader's expectations 
(Graen and Cashman, 1975). This step also makes it possible for the Leader-Member Exchange Theory to be explained by the Social Exchange Theory. Because Social Exchange Theory, which is based on reciprocity norm, states that leader and member reciprocatively have certain expectations and the relationship continues as long as these expectations are fulfilled (Babadag, 2018). In the role-playing step, the leader expects the members to play their roles as per his/her wish and the members who can do this are evaluated in a group with which the leader is in a high-quality relationship and which is seen as an in-group. As a result, the leader offers the employees what they expect in return ( $\mathrm{Li}, 2015)$. Additionally, especially in the role-playing step, it can be said that the relationships between the leader and the members are shaped according to the performance of the followers (Bolat, 2011). The last step is to routinize the role. In this step, the relationship between the leader and the member becomes a routine and both the behaviours of the leader and the members become standardized. This way, the quality of the relationship between the leader and the members starts to become permanent (Bauer and Green, 1996).

In the dual structure that is created between the leader and the followers by a series of role behaviours and social interactions, different behaviours are displayed by the leader and the followers and these behaviours have different reflections both for the organization and for the employees. For instance, in an in-group or in a group in which the leader has high-quality relationships, the followers make extra efforts for these relationships and feel a personal commitment to their superiors. Also, they engage in activities that would help increase the resources and also motivating and challenging job demands (Tims et al., 2012). As for the leaders, they respond by socially supporting the members with whom they have high-quality relationships, by presenting organizational resources to them and by rewarding them (Schriesheim et al., 2001). In addition to this, the leaders develop low-quality exchange relationships based only on formal work agreement principals with followers who are evaluated in the out-groups or with whom they are in a low-quality relationship (Bauer and Green, 1996). Between the leader and members who are in a low-quality relationship, a low level of trust, influence, and support are seen (Wang et al., 2018). Accordingly, it is expected to see more positive attitudes and behaviours from the followers who are in high-quality relationships with their leaders, towards the organization and the leader. Hence, in previous studies, it was defined that the members who are in a high-quality relationship with the leaders show increased organizational commitment, work engagement, job satisfaction, performance, organizational citizenship behaviour and decreased intention to leave (Eisenberger et al., 2010; Dulebohn et al., 2012; Gerstner and Day, 1997; Hsieh, 2012; Ilies et al., 2007; Martin et al., 2016; Radstaak and Hennes, 2017; Venkataramani et al., 2010). For this reason, it can be stated that the highquality relationship between leaders and members is a more desired kind of exchange for organizations.

\subsection{The relation between the Leader-Member Exchange and Job Crafting}

The concept of job crafting, which was brought in the literature in a 2001 study by Wrzesniewski and Dutton, is a behaviour pattern in which the employees re-design their work (Wrzesniewski and Dutton 2001). In job crafting, employees take personal initiatives to change their tasks or the attributes of their work (Tims et al., 2012). This way, the employee is freed from being a passive factor in job crafting behaviour (Kerse, 2017) and is able to redesign his/her work as per personal interest or values. As a result, the work becomes more suitable to the employee's skills and expectations (Tims et al., 2015).

When the results of the job crafting are reviewed, it is seen that job crafting brings along many positive outcomes for organizations (Cheng et al., 2016; Ogbuanya and Chukwuedo, 2017; Singh and Singh, 2018; Zito et al., 2019). For this reason, for organizations, job crafting can be evaluated as an important way of behaviour that needs to be revealed. Many factors reveal job crafting. As a result of the literature review, some of these factors are determined. Some of these factors revealing job crafting are personality traits (Bell and Njoli, 2016; Rudolph et al., 2017), need for personal growth (Hornung, 2017), self-efficacy (Tims et al., 2014), management type, leadership style (Bavik et al., 2017; Kerse and Babadag, 2019; Radstaak and Hennes, 2017), job characteristics (Sen and Dulara, 2017).

It is reckoned that the leader-member exchange is also among the factors revealing job crafting (Li, 2015). The main reason for this exchange can be explained with the social exchange theory. Because, as expressed earlier, as per social exchange theory, as long as the leader and the member mutually fulfill each other's expectations, the mutual exchange continues. In leader-member exchange, the leader offers plenty of resources to the member with whom they are in a high-quality relationship or in other words, who they evaluate as inside the 


\section{Babadağ 12/4 (2020) 3350-3368}

in-group. Among these resources, the leader displays many different behaviours such as social and emotional support, providing autonomy, giving more responsibility, providing information and feedback, and enabling them to join the decision-making processes (Berdicchia and Masino, 2017). To provide more benefit to the leader, the employees may have more work motivation in return (Liden et al., 1997). Additionally, in a work environment like this, employees will feel psychologically more secure and with this sense of security, they take more risks within the scope of their work and make changes (Radstaak and Hennes, 2017). With the change done in the scope of work, the employee may think that he/she will become wore successfully and as a response to the resources provided by the supervisor, he/she will be able to do things that will bring more benefits to the supervisor and the organization. On the other hand, with the sense of security given by the high-quality leader-member exchange, even if the performed change on the scope of work brings negative outputs, the employee may think that the supervisor will defend himself/herself. When the literature is reviewed, it is seen that studies are supporting this thought. For instance, $\operatorname{Li}$ (2015) performed a study in China with a large public corporation and collected data from 277 participants. As a result of this study, it was seen that high-quality leader-member exchange has a positive and significant effect on job crafting. Berdicchia and Masino (2017), collected data from 172 employees of a large Italian wholesale company and saw after the analysis that high-quality leader-member exchange has a positive and significant effect on job crafting as well. Van Dam et al. (2013) collected data from 260 employees from different companies and concluded that highquality leader-member exchange increases job crafting. In parallel with these explanations and research findings, the below hypothesis is developed.

H1: High-quality leader-member exchange has a positive and significant effect on job crafting.

\subsection{The Relation Between Leader-Member Exchange and Perception of Supervisor Support}

Employees believe that the organization has a negative or positive opinion about their contributions and also their happiness is cared for by the organization (Eisenberger et al., 2002). What clarifies this thought is the behaviour and attitude of supervisors towards employees. Because the supervisors represent the organization by being the ones who evaluate and direct the performance of employees (Eisenberger et al., 1986). For this reason, while the positive behaviour and attitude of supervisors imply the existence of supervisor support, negative behaviour and attitude imply otherwise. Among the other behaviour that imply the existence of supervisor support, one can consider assigning tasks which may enable the employees to develop new skills, sparing the time about employees' career goals, and supporting training plans intended for the employees' career goals (Cakmak-Otluoglu, 2012), guiding the employees, and providing feedback about the activities of employees (Yang et al., 2018). All these and similar behaviours increase the perception of supervisor support in an employee. Increased supervisor support perception leads to many beneficial outcomes for organizations. Some of these outcomes include a decrease in job stress (Yang, et al., 2016), exhaustion (Emhan et al., 2014); and an increase in organizational commitment (Cakmak-Otluoglu, 2012) and job satisfaction (Qureshi et al., 2018). Thus, it will not be wrong to say that supervisor support is a very important factor for organizations.

It is considered that leader-member exchange will affect the perception of supervisor support. Because as stated earlier, in leader-member exchange, the leaders divide the employees into two groups such as the ones they are in a high-quality relationship with and the ones they are in a low-quality relationship with. And the leaders offer more social support and organizational resources to the ones in high-quality relationship group (Schriesheim et al., 2001). On the other hand, they only fulfill the requisites of the formal work agreement with the ones in low-quality relationship groups (Bauer and Green, 1996). For this reason, it is expected from the employees who have a high-quality relationship with their leaders to have a high perception of supervisor support. Studies are confirming this high perception in the literature. In one of these studies, Hsieh (2012) collected data from 370 bank employees and as a result of the study, it was concluded that high-quality leadermember exchange affects the perception of supervisor support positively and significantly. In the study Bryant (2008) performed, it was similarly concluded that leader-member exchange has a positive and significant effect on the perception of supervisor support. As per the above discussion and research findings, the below hypothesis is developed.

$\mathrm{H} 2$ : High-quality leader-member exchange has a positive and significant effect on the perception of supervisor support. 


\subsection{The Relation Between Leader-Member Exchange, Perception of Supervisor Support and Job Crafting}

The relation between the perception of supervisor support and job crafting can be explained with Fredrickson's (2001) Broaden-and-Build Theory of Positive Emotions. Because according to the theory, positive emotion experiences, help individuals create personal resources, from physiological and intellectual resources to social and psychological ones. Additionally, along with claiming to broaden the individuals' thought-action repertoires, it also suggests that positive emotions revive the individuals' urges to look for new information, to gain experiences, and to discover (Fredrickson, 2001). Moreover, it states that individuals who experience positive emotions are capable of more holistic thoughts, have stronger attention, and are able to notice smaller details (Fredrickson, 2013) as well as being able to exhibit more creative ideas and actions at work (Kim et al, 2018). Considering all of these explanations, literature shows that organizational support reveals positive emotions (Arnold and Dupré, 2012). Supervisor support can be considered as organizational support by employees (Eisenberger et al., 2002). For this reason, it can be reckoned that supervisor support will reveal positive emotions in employees. As a result of the perception of supervisor support, the employees with revealed positive emotions would be able to make changes in the scope and limits of the work. When literature is reviewed, it is seen that there is a limited number of studies supporting this idea. One of these studies was performed by Kim et al. (2018) with employees of a five-star hotel in South Korea. As a result of this study, it was seen that perception of supervisor support has a positive and significant effect on job crafting, relational crafting, and cognitive crafting. Leana et al. (2009) concluded from their study that supportive management has a positive and significant effect on collaborative job crafting. In light of these statements, the below hypothesis is developed.

H3: Perception of supervisor support has a positive and significant effect on job crafting.

Along with these statements, it is considered that in the effect of high-quality leader-member exchange on job crafting, perceived supervisor support has an mediating role. As the leader offers more support to the employees with whom they are in high-quality relationships, this will enable supervisor support to be perceived and as a result, the employees will psychologically feel more secure and will be able to make changes on the scope of their work. However, there were no studies seen in the literature which present the mediating role of supervisor support on the relation between leader-member exchange and job crafting. On the other hand, as previously stated, there are studies in the literature showing the existence of the dual relationship between these variables (Berdicchia and Masino, 2017; Bryant, 2008; Hsieh, 2012; Kim et al., 2018; Leana et al., 2009; Li, 2015; Van Dam et al., 2013). Additionally, there are studies in the literature evaluating supervisor support as a mediating variable in the relations of other variables. For instance, Hsieh (2012) concluded as a result of the study performed on bank employees that in the relation between high-quality leader-member exchange and organizational commitment, perceived supervisor support has a mediating role. Park and Jang (2017), in the study they developed in the USA, have seen that perceived supervisor support has a partial mediating role in the relation between job autonomy and mental health. As can be seen with these examples, perceived supervisor support has mediating roles between different variables. From this point of view, it can also be said that perceived supervisor support may have a mediating role in the relation between high-quality leader-member exchange and job crafting. In light of these explanations, the below hypothesis is developed.

H4: Perceived supervisor support has a mediating role in the relation between high-quality leader-member exchange and job crafting.

\subsection{Moderating Role of Self-Efficacy in the Relation Between Perceived Supervisor Support and Job Crafting}

Bandura (1977) bases self-efficacy upon social cognitive theory and states that it refers to the faith the individuals have for the skills to achieve certain tasks (Bandura, 1997). In other words, self-efficacy is the faith the individuals have in their skills to successfully complete a task (Bandura, 2009). The individuals who have high assurance about their skills think of the challenging tasks as difficulties to be addressed, not as threats to avoid (Bandura, 1994). However, when an individual thinks his/her skills are not enough for that work, he/she avoids doing it (Bandura, 1977). From this point of view, it can be stated that the perception of self-efficacy has an impact on individuals' behaviours (Bandura and Adams, 1977). As a matter of fact, in organizations, it is observed that the individuals who have a high sense of self-efficacy keep on staying with their tasks even when they come across difficulties and misfortunes, make more efforts, handle stressful situations more 
efficiently and show more proactive behaviours compared to the individuals who have a low sense of selfefficacy (Kanten, 2014; Niessen et al., 2016).

Since job crafting is evaluated as a proactive behaviour pattern, it is projected that a high sense of self-efficacy would have a similar effect on job crafting as well. Employees with high self-efficacy believe that they can use new resources positively. They may also want the challenging task requests more, without minding the possible sanctions of failure (Berdicchia and Masino, 2017; Morrison and Phelps, 1999). For this reason, it can be stated that self-efficacy has an important effect on the emergence of job crafting behaviours. There are empirical studies in the literature reaching this conclusion (Kanten, 2014; Tims et al., 2014). In addition to this Niessen et al. (2016) found that between the need for human connection and relational crafting, perception of self-efficacy has a moderating role. From this perspective, it can be said that the perception of self-efficacy can also be evaluated as a moderating variable.

It is also reckoned in this study that self-efficacy perception may have a moderating role in the relation between perceived supervisor support and job crafting behaviour. Especially when the employees who perceive their supervisor's support and tend towards job crafting behaviour have a high self-efficacy, an increase in job crafting behaviour is expected. The main reason for this can be explained with the Job Demands-Resources Model / JD-R. According to the Job Demands-Resources Model, it is reckoned that individuals endeavor to increase personal resources, structural job resources, and social job resources. Because individuals with increased resources can more easily deal with difficulties and reach their goals (Xanthopoulou et al., 2009). Self-efficacy is among individuals' personal resources (Schaufeli and Taris, 2014). Supervisor support is among the individuals' social job resources (Tims et al., 2015). For this reason, supervisor support may enable individuals to take risks and handle difficulties easily, when combined with self-efficacy which is seen as a personal resource. From this perspective, it is projected that in the relation between perceived supervisor support and job crafting, self-efficacy may have a moderating role.

H5: Self-efficacy has a moderating role in the relationship between perceived supervisor support and job crafting.

Based on the previously stated information and hypotheses, it is expected to see an increase in the indirect effect of high-quality leader-member exchange on job crafting emerging with supervisor support, when it is combined with self-efficacy. Because, as stated previously, in high-quality leader-member exchange, the leader offers more opportunities to employees with whom they develop a relationship apart from the formal one. This way the employee can perceive the supervisor support more. And as a result, the employee navigates towards job crafting behaviour. In the meantime, when the faith in self and own skills, in other words, selfefficacy is high, the individual is able to take risks more easily and thus it is expected to see an increase in the indirect effect of leader-member exchange on job crafting when combined with perceived supervisor support. There were no studies found evaluating this expectation. However, as stated previously, studies are showing the dual relationships between different variables. As per these studies and explanations, the below hypothesis is developed.

H6: In the indirect effect of high-quality leader-member exchange on job crafting with perceived supervisor support, self-efficacy has a moderating role.

Per these explanations and hypotheses, the below research model is created.

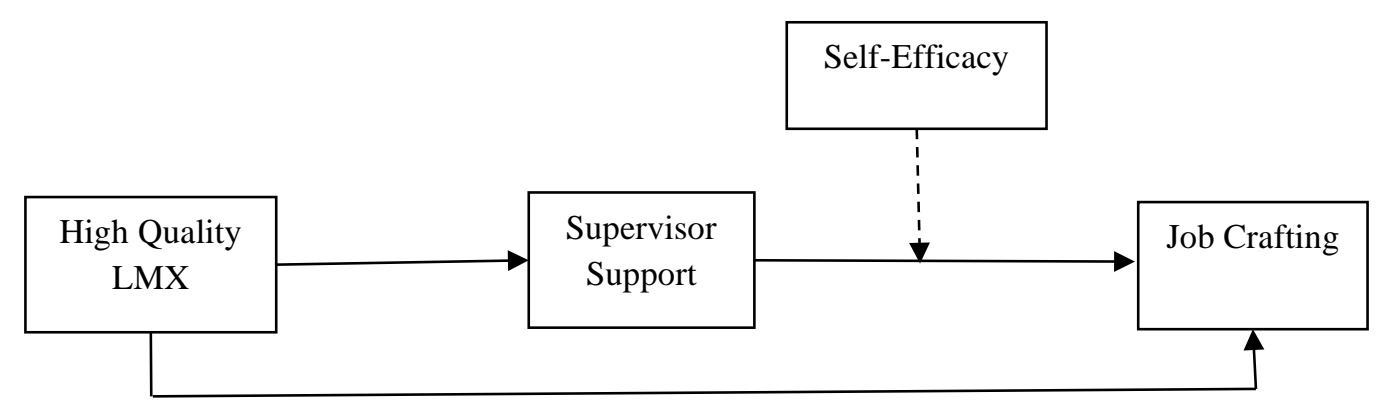

Figure 1. Research Model 


\section{RESEARCH METHOD}

\subsection{The Purpose of the Study, Sample, and Scales}

This study aims to define the mediating role of supervisor support in the effect of high-quality leader-member exchange on job crafting and the moderating role of self-efficacy in the effect of supervisor support on job crafting. The data has been collected via questionnaires and with a simple random sampling method in October and November 2019. The population chosen for this study is teachers of a middle school in a city of Turkey. The participants were asked to join the study voluntarily and 300 questionnaires were distributed to teachers. 243 of the distributed questionnaires were returned. However, due to the fact that there was a loss of data in some of them, the ones with missing answers were left out of the assessment. Finally, 225 questionnaires were assessed.

The questionnaire used in the study consisted of 5 sections and except for the ones asking for demographic data, it used the 5-Point Likert Scale (1-Strongly Disagree 5-Strongly Agree). In the first section of the questionnaire, six questions were asked to gather the demographic information of the teachers. As per the answers of the participating teachers, the demographic data is as follows: $68,9 \%$ of the participants were women and 73,8\% were married. Most of the participants were between the ages of 26 and 35 (44\%). As for the educational background, $90,2 \%$ of the participants had bachelor's degrees. Additionally, most of the participants had been working for the same organization which was the one included in the study for more than 5 years (50,3\%). Finally, 55,1\% of the participants had a monthly income between 4000 TL and 4500 TL.

In the second section of the questionnaire, in order to measure leader-member exchange, Leader-Member Exchange-7 (LMX-7) scale, developed by Scandura and Graen (1984), was used. The scale consists of 7 expressions and measures leader-member exchange under one dimension. In the third section of the questionnaire supervisor support scale, developed by Karasek et al. (1985) was used. There are no sub-factors of this scale and it consists of 7 items. In the fourth section of the questionnaire, the job crafting scale of Slemp and Vella-Brodrick (2013) was used. This scale consists of 19 expressions and 3 sub-dimensions. The researchers who developed the scale named the sub-dimensions of job crafting scale as task crafting, cognitive crafting, and relational crafting. In the fifth section, in order to measure the self-efficacy of participants, Schwarzer and Jerusalem's (1995) General Self Efficacy Scale was used. The scale consists of 10 items and there are no sub-factors.

\subsection{Findings}

\subsubsection{Validity and Reliability Analyses of the Scales}

Scales used in the study are tested for structural validity by using exploratory factor analysis and confirmatory factor analysis. At first, exploratory factor analysis is performed on the scales. In exploratory factor analysis, KMO (Kaiser-Mayer-Olkin) value is expected to be higher than 0,60, and Barlett Sphericity Test value is expected to be significant $(p<0,05)$. Additionally, factor loads are expected to be higher than 0,40 . In light of these values, exploratory factor analysis with varimax rotation is performed on the scales and it is seen that job crafting gathers under 3 sub-factors and leader-member exchange, perceived supervisor support, and selfefficacy consists of 1 factor and that all of the scales meet reference values. Afterward, a confirmatory factor analysis is performed on each scale. In confirmatory factor analysis, the comparative fit index (CFI), the Tucker-Lewis index (TLI), incremental fit index (IFI), root mean square error approximation (RMSEA), standardized root mean residual (SRMR) and $\chi 2$ statistic divided by the degrees of freedom ( $\chi 2 / \mathrm{df})$ indices are used. Regarding model fit, the following conditions are taken as reference: CFI $>0.90$; TLI $>0.90$; IFI $>0.90$; RMSEA $<0.08 ;$ SRMR $<0.10$ and $(\chi 2 / d f) \leq 5$ (Arbuckle, 2006). It is seen that if some modifications were to be made on certain items, the goodness of fit values of the scales would increase. Thus, modifications are made between some items. Finally, it is concluded that referred scales meet the model fit index values (see, Table 1). 
Table 1. Results of Model Fit Index of Scales

\begin{tabular}{|c|c|c|c|c|c|c|}
\hline Variables & $\begin{array}{l}\text { CMIN/DF } \\
\left(0<\chi^{2} / \mathrm{sd} \leq 5\right)\end{array}$ & $\begin{array}{l}\text { SRMR } \\
(\leq, 10)\end{array}$ & $\begin{array}{l}\text { CFI } \\
(\geq, 90)\end{array}$ & $\begin{array}{l}\text { IFI } \\
(\geq, 90)\end{array}$ & $\begin{array}{l}\text { TLI } \\
(\geq, 90)\end{array}$ & $\begin{array}{l}\text { RMSEA } \\
(\leq, 08)\end{array}$ \\
\hline Leader Member Exchange (LMX) & 1,979 & ,020 & ,989 & ,989 & ,980 & ,066 \\
\hline Perceived Supervisor Support (PSS) & 2,337 & ,016 & ,988 & ,988 & ,980 & 077 \\
\hline Self-Efficacy (SE) & 2,141 & ,018 & ,981 & ,982 & ,970 & ,071 \\
\hline Job Crafting (JC) & 2,368 & ,034 & ,928 & ,929 & ,916 & ,078 \\
\hline
\end{tabular}

After eliminating the question marks regarding the structural validity of scales, Cronbach alpha values, which show internal consistency, are calculated in order to define the reliability of scales. For a scale to be accepted as reliable, Cronbach alfa value needs to be at least 0,70 or above (Morgan et al., 2004). As a result of the analysis, the Cronbach alfa value of leader-member exchange was defined as 0,911, perceived supervisor support scale as 0,948 , self-efficacy scale as 0,943 and job crafting scale as 0,935 . These values show that the scales used in this study are reliable. In the study, the average variance extracted (AVE) values and composite reliability values $(C R)$ were also investigated. It is seen that the AVE value of the leader-member exchange scale is $0,657, C R$ value is 0,929 , AVE value of perceived supervisor support scale is $0,765, \mathrm{CR}$ value is 0,957 and AVE value of self-efficacy scale is $0,665, \mathrm{CR}$ value is 0,952 . AVE value of task crafting dimension of job crafting scale is $0,512, \mathrm{CR}$ value is 0,839 , AVE value of cognitive crafting dimension is $0,626, \mathrm{CR}$ value is 0,893 and AVE value of relational crafting dimension is $0,564, C R$ value is 0,886 . These figures show that the scales used in this study meet desired conditions in terms of AVE and CR values. Because to ensure convergent validity, AVE value needs to be higher than 0,50 and CR value needs to be higher than 0,70 , as a prerequisite (Hair et al., 2014).

Later on in the study, a Common method bias analysis is performed. Because during the data collecting phase, the participants were asked to respond to items measuring different variables at the same time. It is reckoned that this may lead to systematic error variance (Podsakoff et al., 2003). This systematic error variance can cause common method bias and can also bias the estimated relationships among variables or measures (Jakobsen and Jensen, 2015; Campbell and Fiske, 1959). For this reason, in order to see whether there is a common method bias, Harman's single-factor test is performed. In the analysis, all of the items related to the scales are included in factor analysis at the same time and no rotation is performed on the factor analysis. As a result of this analysis, it is defined that scale items form a 5-factor structure and that the first factor explains only $42 \%$ of the total variance. Depending on this result, it is concluded that there is no common variance bias (Podsakoff et al., 2003).

\subsubsection{Tests of the Hypotheses}

Before testing the hypotheses, correlation analysis is made to determine the direction and power of the relations between variables and mean values are checked to see the levels of variables. The findings are gathered in Table 2.

Table 2. Correlation Analysis Findings

\begin{tabular}{lllllll}
\hline Variables & $\bar{X}$ & SD & 1 & 2 & 3 & 4 \\
\hline 1-Leader Member Exchange (LMX) & 4,118 &, 729 & 1 & & \\
\hline 2-Perceived Supervisor Support (PSS) & 4,043 &, 644 &, $481^{* *}$ & 1 & & \\
\hline 3-Self-Efficacy (SE) & 4,054 &, 831 &, $891^{* *}$ &, $410^{* *}$ & 1 &, $512^{* *}$ \\
\hline 4-Job Crafting (JC) & 4,171 &, 558 &, $570^{* *}$ &, $713^{* *}$ &, \\
\hline$* * *<01$ & & & & & &
\end{tabular}

When Table 2 is reviewed, it is seen that leader-member exchange has a positive and significant relationship with perceived supervisor support $\left(\mathrm{r}=, 481^{* *}\right)$, and similarly, the leader-member exchange has a positive and significant relationship with self-efficacy $\left(\mathrm{r}=, 891^{* *}\right)$ and job crafting $\left(\mathrm{r}=, 570^{* *}\right)$. Additionally, it is observed from the table that perceived supervisor support has positive and significant relationships between both selfefficacy $\left(\mathrm{r}=, 410^{* *}\right)$ and job crafting $\left(\mathrm{r}=, 713^{* *}\right)$ and self-efficacy has a positive and significant relationship with job crafting $\left(\mathrm{r}=, 512^{* *}\right)$. Apart from these, it is understood from the table that participants perceive a high level 
of leader-member exchange (mean $=4,118$ ) and supervisor support (mean $=4,043$ ) in their organization. Similarly, the self-efficacy of participants is also high (mean $=4,054)$. Participants also show a high level of job crafting behaviour (mean $=4,171)$.

After reaching these findings, whether there is an issue of multicollinearity between independent variables is reviewed. Accordingly, variance inflation factors (VIF) and tolerance indices of independent variables are reviewed and it is seen that; VIF values of variables are below 10 ( $\mathrm{LMX}=5,259$; $P S S=1,303 ; \mathrm{SE}=4,863)$, and tolerance indices are above 0,10 (LMX=,190; $P S S=, 768 ; \mathrm{SE}=, 206)$. For this reason, it is concluded that there are no issues of collinearity. Despite this conclusion, in order to completely contain multicollinearity, analyses are made by centralizing all independent variables, as recommended by Aiken et al. (1991).

Hierarchical regression analysis and Sobel test are performed to show the mediating effect of perceived supervisor support in the effect of high-quality leader-member exchange on job crafting. On the first step, to contain the effects of demographic factors, a model is created which measures the effect of demographic factors on job crafting. In the second step, the leader-member exchange is included in the model. On the third step, the leader-member exchange is removed and perceived supervisor support is added. On the final step, both leader-member exchange and perceived supervisor support are added into the model at the same time and results are evaluated. Another model measuring the effect of leader-member exchange on perceived supervisor support is created and a separate analysis is performed. With this analysis, all of the conditions Baron and Kenny (1986) suggested regarding mediator relations are evaluated. The findings are shown in Table 3.

Table 3. Hierarchical regression analysis results for testing mediation

\begin{tabular}{|c|c|c|c|c|c|c|}
\hline \multirow[t]{2}{*}{ Variables } & \multicolumn{4}{|c|}{$\begin{array}{l}\text { Dependent Variable: } \\
\text { Job Crafting }\end{array}$} & \multicolumn{2}{|c|}{$\begin{array}{l}\text { Dependent Variable: } \\
\text { Perceived Supervisor } \\
\text { Support }\end{array}$} \\
\hline & Step 1 & Step 2 & Step 3 & Step 4 & Step 1 & Step 2 \\
\hline Gender &,- 095 &,- 010 &,- 007 & ,022 &,- 145 &,- 064 \\
\hline Marital Status & ,039 & ,098 & ,015 & ,052 & ,040 & ,096 \\
\hline Age & 026 &,- 002 &,- 003 &,- 013 & 049 & , 022 \\
\hline Educational Level &, $301^{* *}$ & $229 * *$ & ,145 &, 138 & ,257** & , 189 \\
\hline Work Tenure & ,031 & ,042 & ,031 & ,037 & ,218 & ,010 \\
\hline Monthly Income &,- 071 &,$- 082^{* *}$ &,- 038 &,- 051 &,- 055 &,- 065 \\
\hline $\begin{array}{c}\text { Leader Member Exchange } \\
\text { (LMX) }\end{array}$ & - & $439 * *$ & - & $238^{* *}$ & - & $414^{* *}$ \\
\hline $\begin{array}{l}\text { Perceived Supervisor Support } \\
\text { (PSS) }\end{array}$ & - & - & $607^{* *}$ & $483^{* *}$ & - & - \\
\hline F & 1,777 & $17,011^{* *}$ & $33,172 * *$ & $38,573 * *$ & 1,595 & $10,234^{* *}$ \\
\hline $\mathbf{R}^{2}$ & ,047 &, 354 &, 517 &, 588 &, 042 &, 248 \\
\hline Adjusted $\mathbf{R}^{2}$ & ,020 & ,333 &, 501 &, 573 & ,016 & ,224 \\
\hline
\end{tabular}

When Step 2 in the first column of Table 3 is reviewed, it is seen that leader-member exchange has a positive and significant effect on job crafting $(\beta=0.439, \mathrm{p}<0.01)$. Depending on this result, it can be said that H1 (Highquality leader-member exchange has a positive and significant effect on job crafting) is supported. When Step 3 in the first column is reviewed, it is understood that perceived supervisor support has a positive and significant effect on job crafting $(\beta=0.607, \mathrm{p}<0.01$ ). This finding could express that $\mathrm{H} 3$ (Perception of supervisor support has a positive and significant effect on job crafting) is supported as well. On Step 2 of the second column, it can be seen that the leader-member exchange effects perception of supervisor support positively and significantly ( $\beta$ $=0.414, \mathrm{p}<0.01$ ). Thus H2 (High-quality leader-member exchange has a positive and significant effect on the perception of supervisor support) is supported. On step 4 of the first column, leader-member exchange and perceived supervisor support are added into the model at the same time and the effect on job crafting is observed. It is seen that compared to the step (2) in which the effect of leader-member exchange considered by itself, the 
effect is decreased $(\beta=0.238, p<0.01)$. This result implies that on the effect of leader-member exchange on job crafting, perceived supervisor support has a partial mediating role. Additionally, after this result is achieved, the mediating role is reviewed by the Sobel test (1982) and it is defined that perceived supervisor support has a mediating role on the effect of leader-member exchange on job crafting $(p<0.01)$. Hierarchical regression analysis and Sobel test results support H4 (Perceived supervisor support has an intermediary role in the relation between high-quality leader-member exchange and job crafting).

Later on, an analysis is made via Conditional Process Macro, which was developed by Andrew F. Hayes (2013) for SPSS, showing the moderating role of self-efficacy in the effect of supervisor support on job crafting. The results of this analysis are shown in Table 4.

Table 4. Results for testing the moderation of self-efficacy on the relationship between perceived supervisor support and job crafting

\begin{tabular}{lcccccc}
\hline Variables & $\mathbf{B}$ & SE & $\mathbf{t}$ & $\mathbf{p}$ & LLCI & ULCI \\
\hline $\begin{array}{l}\text { Perceived Supervisor Support } \\
\text { (PSS) }\end{array}$ &, 788 &, 1097 & 7,191 &, 0000 &, 5726 & 1,0050 \\
\hline Self-Efficacy (SE) &, 467 &, 1159 & 4,038 &, 0001 &, 2396 &, 6963 \\
\hline PSS*SE (Moderator) &,- 075 &, 0288 & $-2,609$ &, 0097 &,- 1321 &,- 0184 \\
\hline Model Summary & $\mathrm{R}^{2}=, 5790$ & $\mathrm{~F}=101,2956$ & $\mathrm{p}=, 0000$ & & & \\
\hline
\end{tabular}

The Effect of Perceived Supervisor Support on Job Crafting in Different Levels of Self Efficacy

\begin{tabular}{lcccccc}
\hline & Effect & SE & $\mathbf{t}$ & $\mathbf{p}$ & LLCI & ULCI \\
\hline $\mathbf{- 1}$ SD &, 546 &, 0424 & 12,8946 &, 0000 &, 4628 &, 6298 \\
\hline $\mathbf{M}$ &, 483 &, 0442 & 10,9349 &, 0000 &, 3965 &, 5709 \\
\hline $\mathbf{1}$ SD &, 421 &, 0572 & 7,3653 &, 0000 &, 3084 &, 5338 \\
\hline
\end{tabular}

When Table 4 is reviewed, it is understood that the moderating role of self-efficacy on the effect of perceived supervisor support on job crafting is significant $(\mathrm{p}<0.001)$. Also, the fact that LLCI $(-, 1321)$ value, which is the lower limit of the confidence interval and ULCI $(-, 0184)$ value, which is the upper limit of confidence interval do not contain zero is another proof of interaction term to be significant. These proofs show that self-efficacy has a moderator effect on the relationship between perceived supervisor support and job crafting. Besides, as suggested by Aiken et al. (1991), a graphic showing the different levels of moderating variable (low, medium, high) in the effect of the independent variable on the dependent, and this graphic are shown in Figure 2.

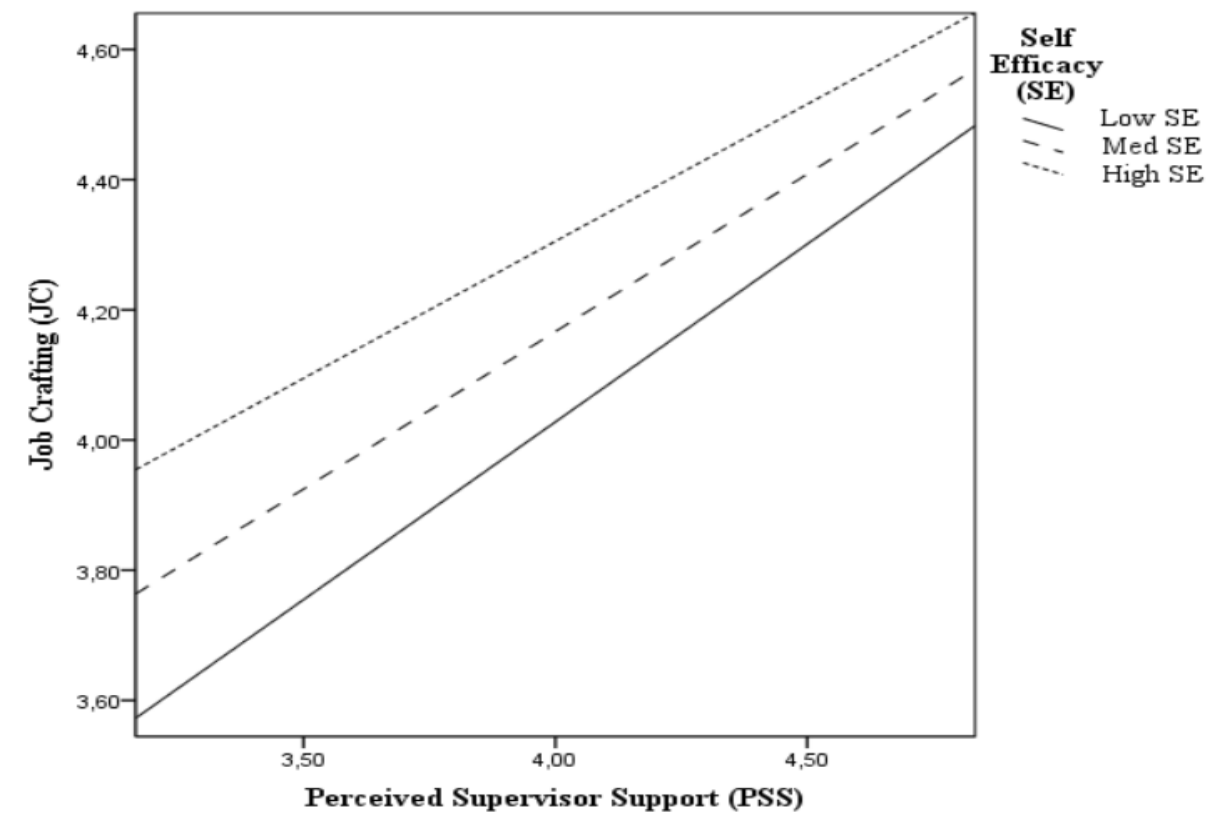

Figure 2. Plots of moderated relationship 
When Figure 2 is reviewed, it is seen that the point where perceived supervisor support has the highest effect on job crafting is the point where self-efficacy is at the highest as well. Additionally, the figure is showing that in the effect of perceived supervisor support on job crafting, different levels of self-efficacy has a moderating role. This finding shows that if the employees who perceive supervisor support have a high self-efficacy, they display job crafting behaviour more. As per the findings of Table 4 and Figure 2, it can be stated that H5 (Selfefficacy may have a moderating role in the relationship between perceived supervisor support and job crafting) is supported.

Based on these findings, it is determined that the required conditions for moderated mediation analysis (Preacher et al., 2007) are fulfilled. Afterward, whether the indirect effect of leader-member exchange on job crafting with supervisor support is based on employees' perception of self-efficacy is defined via moderated mediation analysis. Moderated mediation analysis is performed via Conditional Process Macro, which is developed by Andrew F. Hayes (2013) for SPSS. The number of bootstrap samples is taken as 5000, the confidence interval is taken as $95 \%$ in the analysis. As a result of the study, the index of moderated mediation is seen to be significant (index $=-.0309$; bias and accelerated 95\% CI:,$- 0601-.0057$ ), in other words, in the indirect effect of leader-member exchange on job crafting with perceived supervisor support, self-efficacy has a moderator role. It is also concluded that when self-efficacy is high, the indirect effect of leader-member exchange on job crafting with perceived supervisor support is significant $(\beta=0.194, \mathrm{LLCI}=-, 0499, \mathrm{ULCI}=-$ ,0047). Thus, H6 (In the indirect effect of high-quality leader-member exchange on job crafting with perceived supervisor support, self-efficacy has a moderating role) is supported.

\section{RESULTS AND EVALUATION}

The findings in the literature showing that job crafting increases employees' job satisfaction, job commitment, organization commitment, person-job fit, person-organization fit, organizational citizenship behaviour and performance (Cheng et al., 2016; Ingusci et al., 2016; Irvin, 2017; Kerse, 2018; Kim et al., 2018; Leana et al., 2009; Lee and Lee, 2018; Ogbuanya and Chukwuedo, 2017; Rudolph et al., 2017; Shusha, 2014; Zito et al., 2019) indicate how important job crafting is for the organizations. For this reason, it is believed to be important to look into the factors revealing job crafting. In this context, the study endeavours to evaluate the effect of highquality leader-member exchange perceived supervisor support and self-efficacy on job crafting. In other words, with a multilevel perspective, direct, mediating and moderating effects of leader-member exchange, perceived supervisor support and self-efficacy, all at the same time on job crafting are reviewed. As a result of the study performed with the participation of teachers, it is concluded that high-quality leader-member exchange positively and significantly affects job crafting. It is also defined that in the effect of high-quality leader-member exchange on job crafting, perceived supervisor support has a mediating role. And in the effect of perceived supervisor support on job crafting, self-efficacy has a moderating role. Along with these findings, finally, it is found that self-efficacy has a moderator role in the indirect effect of high-quality leader-member exchange on job crafting with perceived supervisor support. In other words, it is seen that the indirect effect of leader-member exchange and perceived supervisor support on job crafting increases when the employees have high self-efficacy.

\subsection{Theoretical and Practical Inferences}

The study contributes to the literature both theoretically and practically. Primarily, it was investigated whether there were any studies in the literature looking into the effect of leader-member exchange on job crafting and it is seen that within the limited number of studies found, relations with only dual variables are studied (Berdicchia and Masino, 2017; Qi et al., 2019; Radstaak and Hennes, 2017). In the previous studies found in the literature, it is seen that high-quality leader-member exchange positively and significantly affect job crafting. As a result of this study, findings are supporting the studies found in the literature. It is defined in this study that high-quality leader-member exchange effects job crafting positively and significantly. This result shows that job crafting behaviour, which was thought to be a behaviour occurring from the bottom to the top can occur from the top to the bottom as well. Because the leader offers the employees, with whom they developed a close relationship, more resources for job crafting and thus makes job crafting behaviour somewhat easier. As a result, employees are able to show job crafting behaviour.

Secondly, the effect of high-quality leader-member exchange on job crafting is reviewed with a multilevel perspective and also the mediating effect of perceived supervisor support on this relationship is investigated. 


\section{Babadağ 12/4 (2020) 3350-3368}

Additionally, it is considered whether there is a mediating role of self-efficacy in the moderating effect of highquality leader-member exchange and perceived supervisor support on job crafting. As there were no similar studies seen in the literature, the findings of this study are important both for the literature and for the organizations. Additionally, Berdicchia and Masino (2017) looked into the mediating effect of role breadth self-efficacy in the effect of leader-member exchange on job crafting and found that in the effect of leadermember exchange on job crafting, role breadth self-efficacy has a mediating effect. In another study, the effect of job crafting on self-efficacy and the moderator role of leader-member exchange in the effect are reviewed (Gashi et al., 2018). Gashi Tresi and Mihelič found in their study that job crafting effects self-efficacy positively and significantly and also leader-member exchange in this effect has a moderator role. What is different in this study from previous ones is the existence of mediating effect of supervisor support on the effect of leadermember exchange on job crafting is checked and it is found that there was indeed a mediating effect. On the other hand, as a difference from previous studies, the study reviews the moderating role of general selfefficacy in the indirect effect of leader-member exchange and perceived supervisor support on job crafting. As another difference from other studies, the reason behind the fact that general self-efficacy is evaluated as a moderating variable is the thought suggesting that it can exist in individuals independent from these variables. Hence, as a result of the study, it is seen that self-efficacy both has a moderating role in the effect of supervisor support on job crafting and also a moderating effect in the indirect effect of high-quality leader-member exchange and supervisor support on the job.

As a third step, the study contributes to the literature in terms of its sample. Because generally, the studies investigating the effect of leader-member exchange on job crafting used employees of retail companies, mail companies, and manufacturing companies as their sample. (Berdicchia and Masino, 2017; Qi et al., 2019; Radstaak and Hennes, 2017). However, in this study, teachers, who are considered to be of capital importance for societies, are selected as sample. Since there is a limited number of studies in the literature performed on teachers regarding job crafting, it can be stated that the findings of this study are important also in the context of the sample. Additionally, it is an undeniable fact that teachers are utterly important for societies. Because teachers have roles in the development of society as the ones bringing up our children. For a teacher to be able to raise the children and youth properly and to provide them the correct education, first they need to be loving the work they do. Stereotyped methods, in other words, with standard lesson procedures may make the teacher find his/her work boring over time. Many factors would help the teachers overcome this thought. The changes they can do on the scopes of their work is thought to be one of these factors. Indeed, in the study of Bhutta, Hussain and Zhao (2018) performed with university teachers, it is found that job crafting increases job satisfaction. For this reason, due to the positive results the job crafting behaviour of teachers can bring along, the factors helping job crafting behaviour to emerge are investigated in this study. And as a result of this study, it is seen that leader-member exchange, perceived supervisor support, and self-efficacy affects the job crafting behaviour of teachers.

Another contribution of this study to the literature is in terms of culture. Because Turkey is a country with a high power distance (Hofstede, 1983). When the power distance is high in a society, it means that people believe there is inequality among themselves and power becomes centralized in one person or just a few people (Hofstede, 1980). In other words, in societies with high power distance, decisions are made by rulers and society is acting according to these rules. In these kinds of societies, people believe that the ones who have the power would know what is best and expect to be told what to do (Umar and Hassan, 2013). For this reason, in societies with high power distance, individuals in organizations may not be able to show the courage to make changes in the scope of their work. (Wang et al., 2016). Thus, in Turkey, as a society with high power distance, it is expected to see low job crafting. However, as a result of this study, the teachers in the sample showed a high mean value of 4,17 for job crafting behaviour. This result indicates that when the right steps are taken in a society with high power distance, job crafting may increase. From this perspective, it can be stated that a culturally important finding has been achieved.

There are contributions of this study in terms of application as well. In the organizations who want to reveal or increase job crafting behaviour, needs to make sure that first, the leader needs to develop a high-quality relationship with employees. In other words, the leader has to be supporting the employees socially and emotionally, provide autonomy, give more responsibilities, provide information and feedback and also include them in the decision making processes. This way, the employees will perceive the leader as someone 
who is supporting them in the organization and will feel more powerful with support provided them by their leaders. As a result, they may navigate to job crafting behaviour. Additionally, to develop job crafting, There need to be behaviours which would increase self-efficacy as well. In this context, various training programs can be provided to the employees in order to increase their qualifications and skills. As teachers formed the scope of this study, for instance, it can be suggested to direct teachers to post-graduate degrees such as masters or doctorate degrees. This way, the expertise of teachers in their own field of work would be increased. A person with increased qualifications, especially if this increase is related to the field of own work, may have an increased sense of self-efficacy. As per the findings of this research, it can be expected from individuals with high self-efficacy, in a case in which they perceive high-quality leader-member exchange and supervisor support, to navigate to job crafting behaviours.

\subsection{Limitations of Research and Suggestions}

There are some limitations of the study. First of these limitations is the fact that this is a cross-sectional study which reflects the teachers' thoughts at the specific moment of providing their responses. In other words, the participants were asked how much they agree or disagree with the statements in the questionnaire but no further investigation was made about what they think at different times. This situation is a limitation of this study. A longitudinal study would be suggested for the researchers who want to study this topic and want to overcome this limitation and reach more reliable results.

The second limitation of this study is the fact that it is performed with the teachers working in only a city in Turkey. For this reason, the obtained findings cannot be generalized and reflect only the opinions of teachers working in the middle schools of the specific city. For this reason, to be able to generalize the findings, researchers can be advised to perform the research with teachers in different countries and evaluate the results.

The third limitation of the study is the fact that it only examines the effects of variables such as high-quality leader-member exchange, perceived supervisor support, and self-efficacy on job crafting. The reason why this situation is considered a limitation is that factors such as transformational leadership, ethical leadership, organizational culture, organizational climate, management style and the personality traits of employees could also have effects on job crafting. In other words, the study ignored variables that may have effects on job crafting, except for high-quality leader-member exchange, perceived supervisor support and self-efficacy. Additionally, the fact that the study did not make the factors that may be created by job crafting a subject of research could also be considered as a limitation. For this reason, the future researchers who will investigate the subject of job crafting could be recommended to include different variables than the high-quality leadermember exchange, perceived supervisor support, and self-efficacy in their study. They can even be suggested to enlarge the scope of their study by including factors such as job satisfaction, organizational commitment, exhaustion and job alienation which may be affected by job crafting. 


\section{REFERENCES}

Aiken, L. S., West, S. G. and Reno, R. R. (1991). Multiple regression: Testing and interpreting Interactions, Newbury Park, Sage.

Alonso, C., Fernández-Salinero, S. and Topa, G. (2019). The impact of both individual and collaborative job $\begin{array}{lllll}\text { crafting on Spanish teachers' well-being. Education } & \text { Sciences, 9(2), } 74 .\end{array}$ https://doi.org/10.3390/educsci9020074

Alshamasi, A. A. (2012). Effectiveness of leader-member exchange (LMX) in the Saudi workplace context during times of organisational change: an investigation of LMX roles and their potential to enhance employee outcomes (Doctoral dissertation), University of Portsmouth.

Arbuckle J. (2006). Amos 7.0 User's Guide. Amos Development Corporation: Spring House, PA.

Arnold, K.A. and Dupré, K.E. (2012). Perceived organizational support, job-related emotion and employee health. International Journal of Workplace Health Management, 5 (2), 139-152. https://doi.org/10.1108/17538351211239171

Babadag, M. (2018). The Effect of Work Alienation on Cyberloafing Behavior. Balıkesir University The Journal of Social Sciences Institute, 21(39), 207-239. https://doi.org/10.31795/baunsobed.437734

Bandura, A. (1977). Self-efficacy: toward a unifying theory of behavioral change. Psychological review, 84(2), 191-215. https://doi.org/10.1037/0033-295X.84.2.191

Bandura, A. (1994). Self-efficacy. In Ramachaudran, V. S. (Ed.), Encyclopedia of human behavior (Vol. 4). New York, Academic Press, 71-78.

Bandura, A. (1997). Self-efficacy: The exercise of control, New York, Freeman.

Bandura, A. (2009). Cultivate self-efficacy for personal and organizational effectiveness. In Locke, E.A. (Ed)., Handbook of principles of organization Behavior (2nd Ed.), New York, Wiley, 179-200.

Bandura, A. and Adams, N. E. (1977). Analysis of self-efficacy theory of behavioral change. Cognitive therapy and research, 1(4), 287-310. https://doi.org/10.1007/BF01663995

Baron, R.M. and Kenny, D.A. (1986). The Moderator-Mediator Variable Distinction in Social Psychological Research Conceptual, Strategic and Statistical Considerations. Journal of Personality and Social Psychology, 51(6), 1173-1182. https://doi.org/10.1037//0022-3514.51.6.1173

Bauer, T. N. and Green, S. G. (1996). Development of leader-member exchange: A longitudinal test. Academy of management journal, 39(6), 1538-1567. https://doi.org/10.5465/257068

Bavik, A., Bavik, Y. L. and Tang, P. M. (2017). Servant leadership, employee job crafting, and citizenship behaviors: A cross-level investigation. Cornell Hospitality Quarterly, 58(4), 364-373. https://doi.org/10.1177/1938965517719282

Bell, C. and Njoli, N. (2016). The role of big five factors on predicting job crafting propensities amongst administrative employees in a South African tertiary institution. SA Journal of Human Resource Management, 14(1), 1-11. https://doi.org/10.4102/sajhrm.v14i1.702

Berdicchia, D. (2015). The relationship between LMX and performance: the mediating role of role breadth self efficacy and crafting challenging job demands. Electronic Journal of Management, 1, 1-28.

Berdicchia, D. and Masino, G. (2017). Exploring the antecedents of job crafting: A conditional process analysis. International Journal of Business and Management, 12(12), 1-14. https://doi.org/10.5539/ijbm.v12n12p1

Bhutta, Z. M., Hussain, K., and Zhao, M. (2018). Job Crafting Practices and Work Satisfaction: Evidence from Higher Education Sector in Shaanxi, China. The New Educational Review, 52(1), 66-75. http://dx.doi.org/10.15804/tner.2018.52.2.05

Bolat, O. İ. (2011). Lider-üye etkileşimi ve tükenmişlik ilişkisi. ISGUC The Journal of Industrial Relations and Human Resources, 13(2), 65-80. 
Bryant, J. L. (2008). Effects of Leader Relationship Quality (LMX), Supervisor Support, and Upward Influence in National Science Foundation Industry /University Cooperative Research Centers. Doctor of Philosophy (PhD), dissertation, Psychology, Old Dominion University.

Cakmak-Otluoğlu, K. O. (2012). Protean and boundaryless career attitudes and organizational commitment: The effects of perceived supervisor support. Journal of Vocational Behavior, 80(3), 638-646. https://doi.org/10.1016/j.jvb.2012.03.001

Campbell, D. T. and Fiske, D. W. (1959). Convergent and Discriminant Validation by the MultitraitMultimethod Matrix. Psychological Bulletin 56(2), 81-105. https://doi.org/10.1037/h0046016

Cekmecelioglu, H. G. and Ulker, F. (2014). Lider-üye etkileşimi ve çalışan tutumları üzerindeki etkisi: eğitim sektöründe bir araştırma. Kocaeli Üniversitesi Sosyal Bilimler Dergisi, (28), 35-58. https://dergipark.org.tr/en/pub/kosbed/issue/25691/271129

Cheng, J.-C., Chen, C.-Y., Teng, H.-Y. and Yen, C.-H. (2016). Tour Leaders' Job Crafting and Job Outcomes: The Moderating Role of Perceived Organizational Support. Tourism Management Perspectives, 20, 1929. https://doi.org/10.1016/j.tmp.2016.06.001

Colak, I., Altınkurt, Y. and Yılmaz, K. (2017). Öğretmenlerin özerklik davranışları ile iş doyumları arasındaki $\begin{array}{llll}\text { ilişki. Karadeniz Sosyal } & \text { Bilimler } & \text { Dergisi, 9(2), }\end{array}$ https://dergipark.org.tr/en/pub/ksbd/issue/34220/383408

Dulebohn, J. H., Bommer, W. H., Liden, R. C., Brouer, R. L., and Ferris, G. R. (2012). A Meta-Analysis of Antecedents and Consequences of Leader-Member Exchange: Integrating the Past With an Eye Toward the Future. Journal of Management, 38(6), 1715-1759. https://doi.org/10.1177/0149206311415280

Eisenberger, R., Huntington, R., Hutchison, S. and Sowa, D. (1986). Perceived organizational support. Journal of Applied Psychology, 71(3), 500-507. https://doi.org/10.1037/0021-9010.71.3.500

Eisenberger, R., Karagonlar, G., Stinglhamber, F., Neves, P., Becker, T. E., Gonzalez Morales, M. G., and Steiger-Mueller, M. (2010). Leader-member exchange and affective organizational commitment: The contribution of supervisor's organizational embodiment. Journal of Applied psychology, 95(6), 1085-1103. https://doi.org/10.1037/a0020858

Eisenberger, R., Stinglhamber, F., Vandenberghe, C., Sucharski, I. L. and Rhoades, L. (2002). Perceived supervisor support: Contributions to perceived organizational support and employee retention. Journal of Applied Psychology, 87(3), 565-573. https://doi.org/10.1037/0021-9010.87.3.565

Emhan, A., Mengenci, C., Taşdöven, H. and Garayev, V. (2014). Yapısal eşitlik modeli kullanılarak iş memnuniyeti, yönetici desteği ve tükenmişlik kavramları arasındaki ilişkilerin analizi: bankacıllk sektöründe bir uygulama. Sosyal Ekonomik Araştırmalar Dergisi, (27), 75-96. https://doi.org/10.30976/susead.302219

Fredrickson, B. L. (2001). The role of positive emotions in positive psychology: The broaden-and-build theory of positive emotions. American psychologist, 56(3), 218-226. https://doi.org/10.1037/0003-066X.56.3.218

Fredrickson, B. L. (2013). Positive emotions broaden and build. In Advances in experimental social psychology, 47, 1-53. https://doi.org/10.1016/B978-0-12-407236-7.00001-2

Garg, K., Dar, I. A. and Mishra, M. (2018). Job satisfaction and work engagement: A study using private sector bank managers. Advances in Developing Human Resources, 20(1), 58-71. https://doi.org/10.1177/1523422317742987

Gashi Tresi, D. and Mihelič, K. (2018). The roles of self-efficacy and leader-member exchange in the relationship between job crafting and work-self facilitation: A moderated mediation model. Personnel Review, 47(7), 1362-1384. https://doi.org/10.1108/PR-05-2017-0153

Gerstner, C.R. and Day, D.V. (1997). Meta-analytic review of leader-member exchange theory: Correlates and construct issues. Journal of Applied Psychology, 82, 827- 844. https://doi.org/10.1037/0021-9010.82.6.82 
Graen, G. and Cashman, J. F. (1975). A role-making model of leadership in formal organizations: A developmental approach. In Hunt, J. G. \& Larson, L. L. (Eds.), Leadership frontiers, Kent, OH, Kent State University Press, 143-165.

Graen G.B. and Uhl-Bien M. (1995). Relationship-based approach to leadership: Development of leadermember exchange (LMX) theory of leadership over 25 years: Applying a multi-level multi-domain perspective. Leadership Quarterly, 6(2), 219 -247. https://doi.org/10.1016/1048-9843(95)90036-5

Hair, J. F., Black, W. C., Babin, B. J. and Anderson, R. E. (2014). Multivariate data analysis: Pearson new international edition (7th Edition), Essex, Pearson Education Limited.

Hayes, A. F. (2013). Methodology in the social sciences. Introduction to mediation, moderation, and conditional process analysis: A regression-based approach, New York, Guilford Press.

Hofstede, G. (1980). Motivation, Leadership, and Organization: Do American Theories Apply Abroad?. Organizational Dynamics, 9(1), 42-63. https://doi.org/10.1016/0090-2616(80)90013-3

Hofstede, G. (1983). National cultures in four dimensions: A research-based theory of cultural differences among nations. International Studies of Management \& Organization, 13(1-2), 46-74. https://doi.org/10.1080/00208825.1983.11656358

Hornung, S. (2017). Antecedents and outcomes of job crafting: situation-directed and self-directed strategies. T. Mokoaleli-Mokoteli \& Z. Ndaba (Eds.). 5th International Conference on Management Leadership and Governance (ICMLG 2017), 16-17 March 2017, Saint Petersburg, Russia (pp. 175-182).

Hsieh, H. L. (2012). Building employees' organizational commitment with LMX: The mediating role of supervisor support. Global Journal of Engineering Education, 14(3), 250-255.

Ilies, R., Nahrgang, J. D. and Morgeson, F. P. (2007). Leader-member exchange and citizenship behaviors: A meta-analysis. Journal of Applied Psychology, 92(1), 269-277. https://doi.org/10.1037/0021-9010.92.1.269

Ingusci, E., Callea, A., Chirumbolo, A. and Urbini, F. (2016). Job crafting and job satisfaction in a sample of Italian teachers: the mediating role of Perceived Organizational Support. Electronic Journal of Applied Statistical Analysis, 9(4), 675-687. https://doi.org/10.1285/i20705948v9n4p675

Irvin, R. (2017). Job crafting and organizational citizenship behavior: Believing in your creative ability to better your job and organization (Master Dissertation), Kansas State University.

Jakobsen, M. and Jensen, R. (2015). Common method bias in public management studies. International Public Management Journal, 18(1), 3-30. https://doi.org/10.1080/10967494.2014.997906

Kanten, P. (2014). The antecedents of job crafting: Perceived organizational support, job characteristics and self-efficacy. European Journal of Business and Social Sciences, 3(5), 113-128.

Karasek, R. A., Karasek, R., Karasek, R., Karasek Jr, R. A., Gordon-Strachan, G., Pietrowsky, C., ... and Pietrokovsky, C. (1985). Job content questionnaire and user's guide. University of Massachusetts at Lowell, Lowell.

Kerse, G. (2017). Adaptation The Turkish Language of The Job Crafting Scale and Relationship Between Job Crafting and Emotional Exhaustion. Journal of Business Research, 9(4), 283-304. https://doi.org/10.20491/isarder.2017.332

Kerse, G. (2018). The Impact of Job Crafting on Person-Job Fit: “I am Compatible With My Work Because I Can Make Changes in My Work. Atatürk Üniversitesi İktisadi ve İdari Bilimler Fakültesi Dergisi, 32(4), 941-958. https://dergipark.org.tr/tr/pub/atauniiibd/issue/39554/420261

Kerse, G. and Babadag, M. (2019). Dönüştürücü Liderliğin İş Becerikliliği Üzerindeki Etkisi: Akademisyenler Üzerinde Bir Uygulama. İş ve İnsan Dergisi, 6(2), 133-143. https://doi.org/10.18394/iid.504889

Kim, H., Im, J., Qu, H. and NamKoong, J. (2018). Antecedent and consequences of job crafting: an organizational level approach. International Journal of Contemporary Hospitality Management, 30(3), 18631881. https://doi.org/10.1108/IJCHM-01-2017-0040 
Leana, C., Appelbaum, E. and Shevchuk, I. (2009). Work process and quality of care in early childhood education: The role of job crafting. Academy of Management Journal,52(6), 1169-1192. https://doi.org/10.5465/AMJ.2009.47084651

Lee, J. Y. and Lee, Y. (2018). Job crafting and performance: Literature review and implications for human resource development. Human Resource Development Review, 17(3), 277-313. https://doi.org/10.1177/1534484318788269

Li, J. (2015). The mediating roles of job crafting and thriving in the LMX-employee outcomes relationship. Japanese Journal of Administrative Science, 28(1), 39-51. https://doi.org/10.5651/jaas.28.39

Liden, R. C., Sparrowe, R. T. and Wayne, S. J. (1997). Leader-member exchange theory: The past and potential for the future. Research in personnel and human resources management, 15, 47-120.

Mallick, E., Pradhan, R. K. Tewari, H. R., and Jena, L. K. (2014). Organizational citizenship behaviour, job performance and HR practices: A relational perspective. Management and Labour Studies, 39(4), 449460. https://doi.org/10.1177/0258042X15578023

Martin, R., Guillaume, Y., Thomas, G., Lee, A. and Epitropaki, O. (2016). Leader-member exchange (LMX) and

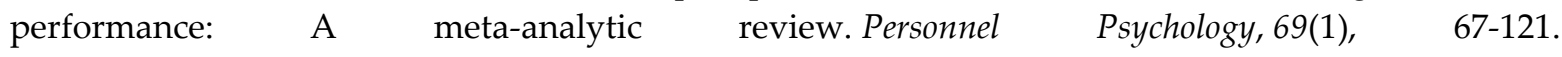
https://doi.org/10.1111/peps.12100

Morgan, G. A., Leech, N. L., Gloeckner, G. W. and Barrett, K. C. (2004). SPSS for Introductory Statistics: Use and Interpretation, New Jersey, Lawrence Erlbaum Associates Publishers.

Morrison, E. W. and Phelps, C. C. (1999). Taking charge at work: Extrarole efforts to initiate workplace change. Academy of management Journal, 42(4), 403-419. https://doi.org/10.5465/257011

Niessen, C., Weseler, D., and Kostova, P. (2016). When and why do individuals craft their jobs? The role of individual motivation and work characteristics for job crafting. human relations, 69(6), 1287-1313. https://doi.org/10.1177/0018726715610642

Ogbuanya, T. C. and Chukwuedo, S. O. (2017). Job crafting-satisfaction relationship in electrical/electronic technology education programme: Do work engagement and commitment matter?. Revista de Psicología del Trabajo y de las Organizaciones, 33(3), 165-173. https://doi.org/10.1016/j.rpto.2017.09.003

Park, R. and Jang, S. J. (2017). Mediating role of perceived supervisor support in the relationship between job autonomy and mental health: moderating role of value-means fit. The International Journal of Human Resource Management, 28(5), 703-723. https://doi.org/10.1080/09585192.2015.1109536

Podsakoff, P. M., MacKenzie, S. B., Lee, J. Y. and Podsakoff, N. P. (2003). Common method biases in behavioral research: a critical review of the literature and recommended remedies. Journal of applied psychology, 88(5), 879-903. https://doi.org/10.1037/0021-9010.88.5.879

Preacher, K. J., Rucker, D. D. and Hayes, A. F. (2007). Addressing moderated mediation hypotheses: Theory,

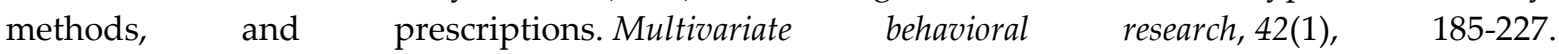
https://doi.org/10.1080/00273170701341316

Qi, J., Zhang, K., Fu, X., Zhao, X., and Wang, L. (2019). The effects of leader-member exchange, internal social capital, and thriving on job crafting. Social Behavior and Personality: An international journal, 47(6), 1-10. https://doi.org/10.2224/sbp.7981

Qureshi, M. A., Hamid, K. B. A., Jeihoony, P., Ali, R., Brohi, N. A., Magsi, R. and Shah, S. M. M. (2018). Is supervisor support matter in job satisfaction? A moderating role of fairness perception among nurses in Pakistan. Academy of Strategic Management Journal, 17(6), 1-10.

Radstaak, M. and Hennes, A. (2017). Leader-member exchange fosters work engagement: The mediating role of job crafting. SA Journal of Industrial Psychology, 43(1), 1-11. https://doi. org/10.4102/sajip.v43. i0.1458

Rudolph, C. W., Katz, I. M., Lavigne, K. N., and Zacher, H. (2017). Job crafting: A meta-analysis of relationships with individual differences, job characteristics, and work outcomes. Journal of Vocational Behavior, 102, 112-138. https://doi.org/10.1016/j.jvb.2017.05.008 
Scandura, T. A. and Graen, G. B. (1984). Moderating Effects of Initial Leader-Member Exchange Status on The Effects of A Leadership Intervention. Journal of Applied Psychology, 69(3), 428-436. https://doi.org/10.1037/0021-9010.69.3.428

Schaufeli, W. B. and Taris, T. W. (2014). A critical review of the job demands-resources model: Implications for improving work and health. In G.F. Bauer and O. Hämmig (Eds.) Bridging occupational, organizational and public health: A Transdisciplinary Approach (pp. 43-68). Springer, Dordrecht.

Schriesheim, C. A., Castro, S. L., Zhou, X. (Tracy) and Yammarino, F. J. (2001). The folly of theorizing "A" but testing "B" A selective level-of-analysis review of the field and a detailed Leader-Member Exchange illustration. The Leadership Quarterly, 12(4), 515-551. https://doi.org/10.1016/S1048-9843(01)00095-9

Schwarzer, R., and Jerusalem, M. (1995). Generalized self-efficacy scale. In Weinman, J., Wright, S. \& Johnston, M. (Eds.), Measures in health psychology: A user's portfolio. Causal and control beliefs, Windsor, UK, NFER-Nelson, 35-37.

Sen, C. and Dulara, S. (2017). Job characteristics and performance: The mediating role of job crafting. The International Journal of Indian Psychology, 5(1), 66-74. https://doi.org/10.25215/0501.068

Shusha, A. (2014). The effects of job crafting on organizational citizenship behavior: Evidence from Egyptian medical centers. International Business Research, 7(6), 140-149. http://dx.doi.org/10.5539/ibr.v7n6p140

Sin, H. P., Nahrgang, J. D. and Morgeson, F. P. (2009). Understanding why they don't see eye to eye: An examination of leader-member exchange (LMX) agreement. Journal of Applied Psychology, 94(4), 10481057. https://doi.org/10.1037/a0014827

Singh, V. and Singh, M. (2018). A burnout model of job crafting: Multiple mediator effects on job performance. IIMB management review, 30(4), 305-315. https://doi.org/10.1016/j.iimb.2018.05.001

Slemp, G. R. and Vella-Brodrick, D. A. (2013). The Job Crafting Questionnaire: A New Scale To Measure The Extent To Which Employees Engage in Job Crafting. International Journal of Wellbeing, 3(2), 126-146. https://doi.org/10.5502/ijw.v3i2.1

Sobel, M. E. (1982). Asymptotic confidence intervals for indirect effects in structural equation models. Sociological methodology, 13, 290-312. https://doi.org/10.2307/270723

Sparrowe, R. T. and Liden, R. C. (1997). Process and structure in leader-member exchange. Academy of Management Review, 22(2), 522-552. https://doi.org/10.5465/amr.1997.9707154068

Tims, M., Bakker, A. B. and Derks, D. (2012). Development and validation of the job crafting scale. Journal of Vocational Behavior, 80(1), 173-186. https://doi.org/10.1016/j.jvb.2011.05.009

Tims, M., Bakker, A. B. and Derks, D. (2014). Daily job crafting and the self-efficacy-performance relationship. Journal of Managerial Psychology, 29(5), 490-507. https://doi.org/10.1108//MP-05-2012-0148

Tims, M., Bakker, A. B. and Derks, D. (2015). Job crafting and job performance: A longitudinal study. European Journal of Work and Organizational Psychology, 24(6), 914-928. https://doi.org/10.1080/1359432X.2014.969245

Umar, M. and Hassan, Z. (2013). Antecedents and Outcomes of Voice and Silence Behaviours of Employees of Tertiary Educational Institutions in Nigeria. Procedia - Social and Behavioral Sciences, 97, 188-193. doi:10.1016/j.sbspro.2013.10.221

Wang, H., Demerouti, E. and Bakker, A. B. (2016). A review of job crafting research: the role of leader behaviors in cultivating successful job crafters. In Parker, S. K. \& Bindl, U. K. (Eds.), Proactivity at Work: Making Things Happen in Organizations. (Series in Organization and Management). London, Taylor and Francis Ltd., 77-104. https://doi.org/10.4324/9781315797113

Wang, H., Wang, X. and Li, J. (2018). Is new generation employees' job crafting beneficial or detrimental to organizations in China? Participative decision-making as a moderator. Asia Pacific Business Review, 24(4), 543-560. https://doi.org/10.1080/13602381.2018.1451129 
Wrzesniewski, A. and Dutton, J.E. (2001). Crafting a Job: Revisioning Employees as Active Crafters of Their Work. Academy of Management Review, 26(2), 179-201. https://doi.org/10.5465/amr.2001.4378011

Van Dam, K., Nikolova, I. and Van Ruysseveldt, J. (2013). Het belang van ‘leader-member exchange'(LMX) en situationele doeloriëntatie als voorspellers van job crafting. Gedrag $\mathcal{E}$ Organisatie, 26(1), 66-84.

Venkataramani, V., Green, S. G. and Schleicher, D. J. (2010). Well-connected leaders: The impact of leaders' social network ties on LMX and members' work attitudes. Journal of Applied Psychology, 95(6), 10711084. https://doi.org/10.1037/a0020214

Xanthopoulou, D., Bakker, A. B., Demerouti, E. and Schaufeli, W. B. (2009). Work engagement and financial returns: A diary study on the role of job and personal resources. Journal of occupational and organizational psychology, 82(1), 183-200. https://doi.org/10.1348/096317908X285633

Yang, F., Liu, J., Huang, X., Qian, J., Wang, T., Wang, Z. and Yu, H. (2018). How supervisory support for career development relates to subordinate work engagement and career outcomes: The moderating role of task proficiency. Human Resource Management Journal, 28(3), 496-509. https://doi.org/10.1111/1748$\underline{8583.12194}$

Yang, T., Shen, Y. M., Zhu, M., Liu, Y., Deng, J., Chen, Q. and See, L. C. (2016). Effects of co-worker and supervisor support on job stress and presenteeism in an aging workforce: a structural equation modelling approach. International journal of environmental research and public health, 13(1), 72. https://doi.org/10.3390/ijerph13010072

Zito, M., Colombo, L., Borgogni, L., Callea, A., Cenciotti, R., Ingusci, E., and Cortese, C. G. (2019). The nature of Job Crafting: Positive and negative Relations with Job satisfaction and work-family conflict. International journal of environmental research and public health, 16(7), 1176. https://doi.org/10.3390/ijerph16071176 